\title{
Hygiene and eating habits of the families with typhoid patients
}

\author{
Nyi Nyi Naing, Zulkifli Ahmad, Abdul Rahman Isa
}

Abstrak

Sejak diketahui penularan demam tifoid terjadi melalui siklus fekal - oral, prosedur higienis memegang peranam utama dalam pencegahan dan pengendalian infeksi. Studi kasus kontrol yang terdiri dari 216 pasien demam tifoid yang telah dikonfirmasi dengan kultur darah atau tes imunologik dibandingkan tingkat kesehatannya berdasarkan umur dan jenis kelamin. Kuesioner y'ang telah disusun digunakan untuk wawancara pasien di Rumah Sakit dan kemudian dilakukan pengamatan higienis dan sanitasi lingkungan di tempat tinggalnya. Pasien dengan riwayat makan makanan yang dibeli dari luar mempunyai risiko yang lebih tinggi untuk terinfeksi. Penyiapan makanan yang tidak hangat dan dibungkus pada waktu pembelian memperlihatkan hubungan yang bermakna dengan terjadinya infeksi. Kebiasaan mengkonsumsi makanan dari pasar malan ditemukan pada 68\% kasus. Faktor kebiasaan makan dan mencuci tangan berperan pada kemungkinan pasien untuk terkena demam tifoid. Cuci tangan sebelum mengambil makanan dan setelah defekasi dilakukan oleh semua pasien tetapi hanya sedikit yang menggunakan sabun untuk mencuci tangan. Hubungan yang bermakna antara status higienis tempat tinggal yang tidak memadai terutama dapur dengan demam tifoid telah terbukti. Program edukasi untuk kebiasaan higienis makanan harus dilaksanakan pada seluruh populasi.

\begin{abstract}
Since the transmission of typhoid fever occurs through fecal-oral cycle, hygienic procedures are taking major role in prevention and control of the infection. A case-control study which consists of 216 patients diagnosed as typhoid fecver confirmed by blood culture or by immunological test were compared to age and sex matched healthy individuals. A well-structured questionnaire was used for interviewing the patients at the hospitals and then observation of domestic hygiene and samitation was done at their residences. Patients with the recent history of eating food bought from outside were at higher risk of getting infection. Prepared not warm food and food wrapped at the time of purchase showed significant association with the infection. Having regular meals from the night market was found in $68 \%$ of the cases. Behavioral factors related to eating and hand washing practices predisposed a patient to typhoid fever. Washing hands before taking meals and after defaecation were found in almost all, but low percentage of cases kept soap for washing hands. A significantly higher association between inadequate hygiene status of the houses and the typhoid fever was existed particularly of the kitchen. The educational programs on specific habits of proper hygiene should be addressed to the entire population. Emphasis on the role of food hygiene should be addressed to highlight the route of infection.
\end{abstract}

Universiti Sains Malaysia, Relantan, Malaysia 